\title{
Energetics and development modes of Asteroidea (Echinodermata) from the Southwestern Atlantic Ocean including Burdwood Bank/MPA Namuncurá
}

\author{
Cintia P. Fraysse ${ }^{1,2} \cdot$ Analía F. Pérez $^{1} \cdot$ Javier A. Calcagno ${ }^{1} \cdot$ Claudia C. Boy $^{2}$
}

Received: 24 September 2018 / Revised: 7 May 2019 / Accepted: 23 August 2019 / Published online: 22 January 2020

(c) Springer-Verlag GmbH Germany, part of Springer Nature 2020

\begin{abstract}
Reproduction is a highly expensive process that during gonadal development requires an important supply of nutrients. The allocation of energy can vary throughout the reproductive cycle, between sexes and development modes. During research cruise aboard the RV Puerto Deseado in April 2016, we collected fifteen species of sea stars from the southernmost region of Argentina. The main purposes of the present study were threefold: first, to revise and report novel information on the reproductive strategies and energetic density (ED) of body components from the asteroids of the southwestern Atlantic Ocean including Burdwood Bank/ MPA Namuncurá; second, to compare the ED of these body components across species with contrasting reproductive strategies; third, to provide a tool to estimate the ED from dry mass of organs of the sea star species examined. Ovaries of Diplopteraster verrucosus (a brooder with a nidamental chamber) revealed a significantly greater ED than did the testes $(29.81 \pm 1.38$ and $17.76 \pm 1.59$, respectively). In Glabraster antarctica (a broadcaster with yolky eggs and facultative planktotrophic larvae), the gonads had EDs of $25.78 \pm 3.16$ and $19.21 \pm 0.52$ (females and males, respectively). While in Peribolaster folliculatus (a broadcaster with eggs with low yolk content and inferred planktotrophic larvae) there was no significant difference in the ED values between sexes (females: $22.79 \pm 1.10$ and males: $20.46 \pm 1.05$ ). For the pyloric caeca, ED values did not reveal any difference between sexes, although in $P$. folliculatus, the ED was significantly higher than that for D. verrucosus and G. antarctica $(25.90 \pm 1.00,23.03 \pm 0.34$, and $22.66 \pm 0.65$, respectively). The body wall had higher ED values in D. verrucosus and P. folliculatus than that for all the sea star species analyzed $(46.48 \pm 1.63$, $51.17 \pm 1.34$, respectively). Higher ED values in the ovaries could be related to the nutrition of offspring, while differences found in the body wall may reflect the skeletal structure of this body component. This research provides basic information for understanding the differences on energetic allocation when contrasting development modes are considered.
\end{abstract}

Keywords Energetics $\cdot$ Development mode $\cdot$ Sea stars $\cdot$ Burdwood Bank/MPA namuncurá $\cdot$ Tierra del fuego

\section{Introduction}

Analía F. Pérez

analiafperez1@gmail.com

$\bowtie$ Claudia C. Boy

claudiaboy@gmail.com

Cintia P. Fraysse

cyn.fraysse@gmail.com

1 Laboratorio de Invertebrados Marinos, CEBBAD, Universidad Maimónides, CONICET, CABA, Buenos Aires, Argentina

2 Laboratorio de Ecología, Fisiología Y Evolución de Organismos Acuáticos, CADIC - CONICET, Ushuaia, Argentina
Sea stars represent a diverse group of benthic invertebrates, with a long paleontological history (Blake 2000; Sutton et al. 2005; Stilwell and Long 2011; Jagt et al. 2014). The Asteroidea have successfully colonized all depths of the world's oceans (Broyer and Koubbi 2014), and have numerous feeding (Jangoux 1982) and reproduction strategies (MacBride 1920; Bosch and Pearse 1990; Pearse et al. 1991; Byrne 2005). Moreover, can serve as top predators playing an important role in structuring benthic communities (Paine 1969; McClintock 1994).

Sea stars exhibit a spectrum of developmental types which includes pelagic or non-pelagic embryos and larvae, and planktotrophic (particulate feeding) or lecithotrophic 
(non-feeding) modes of nutrition (Mileikovsky 1971; Chia 1974; Bosch and Pearse 1990). The larval development of echinoderms can be classified into general categories on the basis of mode of nutrition and habitat (Chia 1974; McEdward and Miner 2001). Larvae may be planktotrophic (feeding on particulate material and nearly always pelagic) or lecithotrophic (non-feeding) (Bosh 1989; McEdward and Miner 2001). In this scenario, lecithotrophic larvae can be pelagic, demersal, or brooded. Many species of sea stars that inhabit high southern latitudes present parental care (Pearse et al. 1991; McEdward 1995; Bosch and Slattery 1999; Fraysse et al. 2018), where embryos are retained at different areas of the female, such as on the aboral surface among spines, over the mouth, inside an aboral nidamental chamber, in the cardiac stomach, or even within the ovaries (intraovarian brooding) (Thomson 1876; Studer 1885; Lieberkind 1920; Himmelman et al. 1982; Chia and Walker 1991; Byrne 1996, 2005; Pérez et al. 2015).

Studies of the energetics of echinoderm body components are of comparative interest, because the distribution and allocation of energy within and between body components of animals can provide important information on their functional roles and relative importance to the survival of the organism (Calow 1984; Lawrence 1987a). Among the Asteroidea, body compartments can be divided into three functional categories: the body wall, which is traditionally considered to serve a structural or protective function, the pyloric caeca, which are nutrient storage organs, and the gonads, the reproductive organs (Hyman 1955; Giese 1966). Both food availability and the biochemical and nutritional composition of the diet may have consequences in patterns of energy allocation to these body components (McClintock et al. 1990, 1995). For example, in high-latitude marine ecosystems, pronounced seasonal fluctuations occur in food availability (Clarke 1987; Almandoz et al. 2011) and in many cases individuals accumulate exceptionally large amounts of energy-rich lipids during spring (Pérez et al. 2008) and summer (McClintock and Pearse 1987) to be utilized during the winter. Use of energy models has grown increasingly since the early fifties (Fernández et al. 2009) since they enabled simplification of the technique, substituting time-consuming proximal analysis or calorimetry for an easier calculation, which is faster and requires no specialized equipment other than an oven. A useful tool for further studies in sea stars from the southwestern Atlantic Ocean, may arise from the relationship between energy density (ED) and dry mass of the body components. Gonadal development in the Asteroidea is closely related with nutrient input (Lawrence 1987b) and ingested energy must be partitioned to growth and maintenance (Lucas 1996). This allocation may fluctuate between sexes and during reproductive cycle (Lawrence and McClintock 1994). Reproductive effort in sea stars can vary with the mode of development. For instance, in species with development modes that imply a planktotrophic stage, reproductive investment is usually equal between the sexes (Raymond et al. 2007; Pérez et al. 2010, 2017), while in species that brood, males may invest more energy in gamete production than females, whereas the latter may face costs associated with incubating embryos (Raymond et al. 2004; Gillespie and McClintock 2007; Pérez et al. 2015). As pyloric caeca serve as nutrient reserve organs (Lawrence $1987 \mathrm{c}$ ), it is not surprising that many asteroids show an inverse relationship in seasonal gonadal and pyloric caeca indices due to the transference of energy and nutrients to developing gonads (Chia and Walker 1991).

The southern Patagonian Shelf (extending from approximately $47^{\circ} \mathrm{S}$ to Cape Horn, $55^{\circ} \mathrm{S}$ ) encompasses a vital marine ecosystem that remains largely unexplored (Sabatini et al. 2004), and includes the Marine Protected Area Namuncurá (MPAN). The circulation over the southern Patagonian shelf is influenced by two branches of the Antarctic Circumpolar Current. There is a direct inflow of cold Antarctic waters to the south (mainly through the Strait of Lemaire, between Tierra del Fuego and Isla de los Estados) and the Malvinas Current flows over the continental shelf, to the east (Sabatini et al. 2004). The latter transports cold, nutrient-rich sub-Antarctic water, corresponding to the subpolar oceanographic system (Falabella 2017). The MPAN shares asteroid species not only with Tierra del Fuego Province (nine species) (Fraysse et al. 2018), but also with Antarctica such as Acodontaster elongatus, Anasterias pedicellaris, Bathybiaster loripes, Henricia studeri, Peribolaster folliculatus, and Pteraster stellifer. The Malvinas Current might thus facilitate the dispersion of asteroid larvae toward the Burdwood Bank plateau, as most of the species shared between the MPAN and Antarctica possess pelagic planktotrophic or lecithotrophic larvae (Fraysse et al. 2018).

The purposes of the present study were threefold: first, to revise and report novel information on the development modes and energetic density of body components from the asteroids of the southwestern Atlantic Ocean; second, to compare the energetic density of these body components across species with contrasting development modes (Diplopteraster verrucosus, Glabraster antarctica, Peribolaster folliculatus, and Anasterias pedicellaris); third, to provide a tool to estimate the energetic density from dry mass of organs of the sea star species examined.

\section{Materials and methods}

During research cruise aboard the RV Puerto Deseado (Scientific cruise BBB-ABR16) in April 2016, different species of sea stars were collected from the southernmost region of Argentina. The sampling spanned a region $53^{\circ} 55.9^{\prime} \mathrm{S}$ to $55^{\circ}$ $2.21^{\prime} \mathrm{S}$ latitude to $67^{\circ} 51.8^{\prime} \mathrm{W}$ to $58^{\circ} 21.61^{\prime} \mathrm{W}$ longitude 
(Fig. 1) that included the Tierra del Fuego Province and the Marine Protected Area Namuncurá (MPAN). The MPAN was established in 2013 on the Burdwood Bank (BB) plateau, and is located about $200 \mathrm{~km}$ south of the Malvinas Islands and $150 \mathrm{~km}$ east from Isla de los Estados. Benthic habitats of the BB seabed had accumulations of sand, gravel, and shell, with depths between 50 and $200 \mathrm{~m}$ and abrupt slopes that exceeded $3000 \mathrm{~m}$ depth delimited the bank (Piola and Gordon 1989; Schejter et al. 2016). Sampling was carried out using a bottom otter trawl (total length $=6 \mathrm{~m}$, headrope and footrope $=6 \mathrm{~m}$, wing mesh $25 \mathrm{~mm}$, cod-end mesh $=10 \mathrm{~mm}$, otter board surface $=0.25 \mathrm{~m}^{2}$, otter board weight $=12 \mathrm{~kg}$, horizontal opening $=1.8 \mathrm{~m}$, vertical opening $=0.60 \mathrm{~m}$ ) and a Rauschert dredge to complement species caught in the trawls with species that live buried in the sediment. Seventeen stations were sampled at different depths (ranging from 92 to $203 \mathrm{~m}$ ) and with different benthos characteristics (i.e., rock, sand, and gravel).

All collected individuals were photographed and then dissected so as to obtain samples to study and evaluate the different modes of development and the energetics of the various body components. Individuals' already dissected bodies were then preserved in formaldehyde $(10 \%)$ for identification to the lowest taxonomic level possible. Initial taxonomic determinations were performed based on Sladen (1889), Koehler (1913), Verrill (1914), Fisher (1940), Bernasconi (1970), Tablado (1982), Clark and Downey (1992), Stampanato and Jangoux (1993), Janosik and Halanych (2010), Mah et al. (2014), and Arntz and Rauschert (2015).
Taxonomic identifications were then matched against the Register of Antarctic Marine Species (Clarke and Johnston 2003; De Broyer et al. 2018), the World Register of Marine Species (Horton et al. 2018), De Broyer and Danis (2010), OBIS (2018), and the World Asteroidea database (Mah 2018) to remove synonymies.

\section{Development mode and energy indexes}

The developmental mode of each species was determined using bibliographic information from MacBride (1920), Lieberkind (1926), Fisher (1940), Hyman (1955), Bernasconi (1970), Bosch (1989), Bosch and Pearse (1990), Pearse et al. (1991), and Pearse and Bosch (1994). For the species in which no information was found in the literature, macroscopic and microscopic observations were made, including recording the presence of embryos, and histological analyses of the gonads including measuring the maximum sizes of oocytes. We ensure to consider mature gonads observing the degree of packaging of the oocytes and noticing the acidophilic cytoplasm. The ovaries of mature females contain large mature ova with acidophilic cytoplasm, densely packed into the lumen, and small number of previtellogenic oocytes located along the acinus wall (Pérez et al. 2010). Histological analysis was carried out on one gonad from each individual that was immersed in Bouin's fixative for $12 \mathrm{~h}$ before dehydration in a graded ethanol series. Tissue was embedded in paraffin (Paraplast $\left.{ }^{\circledR}\right)$ and 5-7 $\mu \mathrm{m}$ sections were cut and stained
Fig. 1 Map showing the location of the sampling area on April 2016. The 50-m, 200-m, $1000-\mathrm{m}, 2000-\mathrm{m}$ isobaths, and the scale bar are included. For the detailed position of the seventeen sample sites see Fraysse et al. (2018)

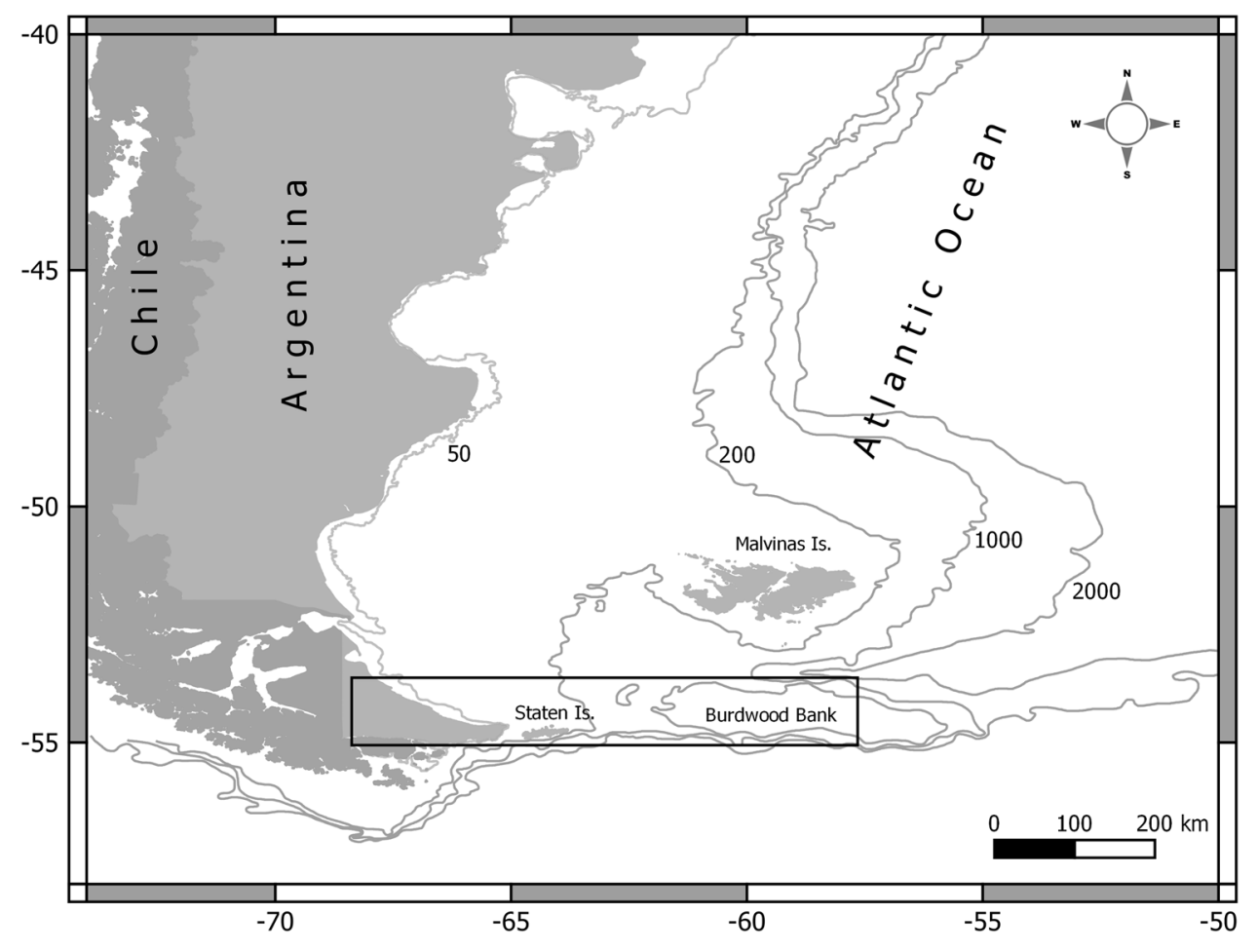


with hematoxylin-eosin (Pérez et al. 2010). Histological slides from 193 individuals of different species were examined microscopically. Sections were imaged with a digital camera attached to an Olympus BX40 microscope and analyzed using Micrometrics SE Premium 4 software.

For calorimetric determinations, sub-samples of body components (gonads, pyloric caeca and body wall) were stored at $-20{ }^{\circ} \mathrm{C}$ until processing. Each component was weighted to determine the wet mass and then dried in a drying oven at $60{ }^{\circ} \mathrm{C}$ until attaining constant dry mass. Dry material of each sample was then pulverized using a mortar and pestle, and pellets $(0.02-0.2 \mathrm{~g})$ were made with a Parr 2812 press. Energetic density (ED) was determined by complete combustion of each pellet in a semi-micro calorimeter (Parr 1425) following the methodology of Lucas (1996) with the modifications made by Pérez et al. (2008) and Boy et al. (2009). Data were converted to kilojoules per g dry mass of ash-free material (energetic density, ED, $\mathrm{kJ} \mathrm{g}^{-1}$ AFDM). Periodic calibrations were made with benzoic acid. Inorganic matter (IM) was calculated as the percentage of residuals (ashes) after the combustion.

\section{Energetics of sea stars with contrasting development modes}

To compare the energetic density (ED) of gonads and pyloric caeca of species with different developmental modes, three species with sufficient sample sizes were selected: Diplopteraster verrucosus (brooders with incubation in nidamental chamber; Bernasconi 1970), Glabraster antarctica (broadcaster with eggs with low yolk content and facultative planktotrophic larvae; Bosch 1989; Moore et al. 2018), and Peribolaster folliculatus (broadcasters with presumptive planktotrophic larvae; present paper). In the particular case of the body wall, Anasterias pedicellaris (brooders with oral incubation) was added to the ED comparisons to facilitate a better understanding of the relation between development mode and the energetics of this body component. Finally, the relationships between ED and dry mass (DM) of each body component were analyzed.

\section{ED estimations}

Regression analyses were performed to study the relationship between ED ( $\mathrm{kJ} \mathrm{g}^{-1}$ AFDM) and DM (\%) of the body components from all the species analyzed. An overall analysis was performed first for each body component, and then each species were studied. Those species where the regression was found significant are reported separately.

\section{Statistical analyses}

Two-way ANOVAs were performed to analyze the effect of sex and developmental mode on the ED of the different body components followed by Tukey comparisons. In all cases, the assumptions of normality and homogeneity of variances were tested using Kolmogorov-Smirnov and Levene test, respectively. When necessary, logarithmic transformations were applied (Sokal and Rohlf 1995) and non-parametric statistical method was used (Mann Whitney). The relationship between ED $\left(\mathrm{kJ} \mathrm{g}^{-1}\right)$ and DM (\%) of gonad, pyloric caeca, and body wall for the species of the asteroids was determined using linear regression analysis. All analyses were performed using GraphPad Prism 6.0, Statistica 10 and QGIS 2.18.3.

\section{Results}

The fifteen species of sea stars collected from the southwestern Atlantic Ocean are shown in Table 1.

\section{Development mode and energy indexes}

Taxonomy, development mode, values of wet mass, energetic density (ED), and inorganic matter (IM) for each body component for each species of sea star are summarized in Table 1.

Regarding the species with development modes not identified through the literature, macroscopic and microscopic observations were performed. Histological slides of gonads (108 females, 81 males) of different species were examined. In both Anasterias pedicellaris (Fig. 2a) and Lysasterias $\mathrm{sp}$., brooded embryos were found being held over the oral opening of adult females, while histological sections of the gonads of presumptive mature (non-brooding) females revealed few numbers of large densely packed acidophilic oocytes with a maximum diameter of $2.44 \mathrm{~mm}$. Histological sections of gonads of Henricia obesa (Fig. 2b) and Henricia. studeri females similarly revealed few numbers of large densely packed acidophilic oocytes with a maximum diameter of $1.03 \mathrm{~mm}$ along with numerous smaller previtellogenic oocytes. In Peribolaster folliculatus (Fig. 2c), histological sections of the ovaries revealed a large number of small oocytes with a maximum diameter of $0.18 \mathrm{~mm}$.

ED values of the species examined for the ovaries varied from 22.56 to $29.81 \mathrm{~kJ} \mathrm{~g}^{-1}$, with a mean value of $25.56 \mathrm{~kJ}$ $\mathrm{g}^{-1}$ (Table 1) with A. pedicellaris having the lowest and Diplopteraster verrucosus the highest ED. The mean ED of male gonads (testes) was lower than that found in females (21.11 $\left.\mathrm{kJ} \mathrm{g}^{-1}\right)$. Testes of $D$. verrucosus had the lowest $\mathrm{ED}\left(17.76 \mathrm{~kJ} \mathrm{~g}^{-1}\right)$ and $C$. lurida had the highest $(24.86 \mathrm{~kJ}$ $\mathrm{g}^{-1}$ ). The mean ED for the pyloric caeca of the species 
Table 1 Taxonomy, developmental mode, wet mass (\%), energetic density (ED, $\mathrm{kJ} \mathrm{g}^{-1}$ AFDM), and inorganic matter (IM, \%) of gonad, pyloric caeca, and body wall of different species of asteroids from the studied area

\begin{tabular}{|c|c|c|c|c|c|}
\hline Family & Species & Development mode & Wet mass (\%) & $\mathrm{ED}\left(\mathrm{kJ} \mathrm{g}^{-1}\right) \mathrm{AFDM}$ & $\operatorname{IM}(\%)$ \\
\hline \multirow[t]{14}{*}{ Asteriidae } & Anasterias pedicellaris & \multirow{5}{*}{$\begin{array}{l}\text { Brooders (oi) with lecithotrophic } \\
\text { embryos* }\end{array}$} & & & \\
\hline & Gonad (females) & & $92.37(1)$ & $22.56 \pm 4.75(2)$ & $10.46(1)$ \\
\hline & Gonad (males) & & - & $19.29 \pm 4.53(2)$ & $21.12(1)$ \\
\hline & Pyloric caeca & & - & $20.24 \pm 3.44$ & - \\
\hline & Body wall & & - & $2.97 \pm 0.19(10)$ & $63.54 \pm 2.06(10)$ \\
\hline & $\begin{array}{l}\text { Cryptasterias turqueti } \\
\text { Gonad (females) }\end{array}$ & \multirow[t]{3}{*}{$\begin{array}{l}\text { Brooders (oi) with lecithotrophic } \\
\text { embryos }^{\mathrm{a}}\end{array}$} & $76.63 \pm 2.39(6)$ & - & - \\
\hline & Pyloric caeca & & $69.21(1)$ & $25.97(1)$ & $3.96(1)$ \\
\hline & Body wall & & - & $3.96 \pm 0.22(9)$ & $53.68 \pm 2.70(9)$ \\
\hline & Diplasterias brandti & \multirow{5}{*}{$\begin{array}{l}\text { Brooders (oi) with lecithotrophic } \\
\text { embryos }^{\mathrm{a}}\end{array}$} & & & \\
\hline & Gonad (females) & & $85.62 \pm 0.89(2)$ & - & - \\
\hline & Gonad (males) & & $87.19 \pm 3.36(3)$ & $23.02(1)$ & - \\
\hline & Pyloric caeca & & $81.08 \pm 3.28(5)$ & $25.92 \pm 0.85(2)$ & $2.23 \pm 0.36(2)$ \\
\hline & Body wall & & $64.25 \pm 0.87(4)$ & $3.68 \pm 0.43(8)$ & $60.23 \pm 3.56(8)$ \\
\hline & $\begin{array}{l}\text { Lysasterias sp. } \\
\text { Body wall }\end{array}$ & $\begin{array}{l}\text { Brooders (oi) with lecithotrophic } \\
\text { embryos* }\end{array}$ & - & $1.88(1)$ & $77.14(1)$ \\
\hline \multirow[t]{4}{*}{ Stichasteridae } & $\begin{array}{l}\text { Cosmasterias lurida } \\
\text { Gonad (females) }\end{array}$ & \multirow[t]{4}{*}{$\begin{array}{l}\text { Broadcasters with planktotrophic } \\
\text { larvae }^{b}\end{array}$} & $87.72 \pm 1.06(3)$ & $23.98 \pm 2.35(5)$ & $6.93 \pm 0.76(4)$ \\
\hline & Gonad (males) & & $91.77 \pm 0.67(2)$ & $24.86 \pm 1.56(3)$ & $4.66(1)$ \\
\hline & Pyloric caeca & & $74.61 \pm 1.08(5)$ & $26.12 \pm 0.69(7)$ & $3.25 \pm 0.94(5)$ \\
\hline & Body wall & & $65.29 \pm 0.34(5)$ & $3.56 \pm 0.28(8)$ & $59.33 \pm 2.15(5)$ \\
\hline \multirow[t]{10}{*}{ Echinasteridae } & Henricia obesa & \multirow[t]{5}{*}{ Broadcasters with yolky eggs* } & & & \\
\hline & Gonad (females) & & $68.07 \pm 0.85(2)$ & $28.65 \pm 3.10$ & $4.71 \pm 1.12(2)$ \\
\hline & Gonad (males) & & $82.83 \pm 0.79(4)$ & $23.19 \pm 0.99(3)$ & - \\
\hline & Pyloric caeca & & $81.61 \pm 2.71(4)$ & $22.92 \pm 1.55$ & $0.88(1)$ \\
\hline & Body wall & & $61.88 \pm 1.41(4)$ & $5.40 \pm 0.28(6)$ & $49.23 \pm 7.58(2)$ \\
\hline & Henricia studeri & \multirow[t]{5}{*}{ Broadcasters with yolky eggs* } & & & \\
\hline & Gonad (females) & & $85.14 \pm 7.56(2)$ & $25.38 \pm 1.88(2)$ & $9.76(1)$ \\
\hline & Gonad (males) & & $79.06(1)$ & - & - \\
\hline & Pyloric caeca & & $76.60 \pm 1.18(3)$ & $22.76 \pm 1.46(4)$ & $6.80 \pm 1.24(2)$ \\
\hline & Body wall & & $66.82 \pm 1.01(3)$ & $5.60 \pm 0.40(5)$ & $60.76(1)$ \\
\hline \multirow[t]{8}{*}{ Goniasteridae } & Ceramaster patagonicus & \multirow{8}{*}{$\begin{array}{l}\text { Broadcasters with lecithotrophic } \\
\text { larvae }^{\mathrm{c}}\end{array}$} & & & \\
\hline & Gonad (females) & & $86.40(1)$ & - & - \\
\hline & Gonad (males) & & $60.58(1)$ & - & - \\
\hline & Pyloric caeca & & - & $21.73(1)$ & $6.25(1)$ \\
\hline & Body wall & & - & $2.87 \pm 0.28$ & $68.71 \pm 2.28(4)$ \\
\hline & Hippasterias falklandica & & & & \\
\hline & Pyloric caeca & & - & $21.18 \pm 1.88(2)$ & $2.89(1)$ \\
\hline & Body wall & & - & $5.41 \pm 0.718$ & $48.09 \pm 2.96(4)$ \\
\hline \multirow[t]{6}{*}{ Odontasteridae } & Acodontaster elongatus & \multirow{3}{*}{$\begin{array}{l}\text { Broadcasters with lecithotrophic } \\
\text { larvae }^{c}\end{array}$} & & & \\
\hline & Gonad (females) & & $81.51(1)$ & - & - \\
\hline & Body wall & & - & $4.09(1)$ & $54.30(1)$ \\
\hline & $\begin{array}{l}\text { Diplodontias singularis } \\
\text { Body wall }\end{array}$ & $\begin{array}{l}\text { Broadcasters with planktotrophic } \\
\text { larvae }^{\mathrm{d}}\end{array}$ & - & $\begin{array}{l}- \\
2.09(1)\end{array}$ & $\begin{array}{l}- \\
58.30(1)\end{array}$ \\
\hline & $\begin{array}{l}\text { Odontaster penicillatus } \\
\text { Pyloric caeca }\end{array}$ & \multirow[t]{2}{*}{$\begin{array}{l}\text { Broadcasters with planktotrophic } \\
\text { larvae }^{\mathrm{d}}\end{array}$} & $82.16 \pm 1.48(2)$ & $21.84 \pm 1.22(2)$ & $22.01(1)$ \\
\hline & Body wall & & $62.19 \pm 7.05(2)$ & $3.40 \pm 0.62$ & $57.68 \pm 3.25(2)$ \\
\hline
\end{tabular}


Table 1 (continued)

\begin{tabular}{|c|c|c|c|c|c|}
\hline Family & Species & Development mode & Wet mass $(\%)$ & $\mathrm{ED}\left(\mathrm{kJ} \mathrm{g}^{-1}\right) \mathrm{AFDM}$ & $\mathrm{IM}(\%)$ \\
\hline \multirow[t]{5}{*}{ Poraniidae } & Glabraster antarctica & \multirow{5}{*}{$\begin{array}{l}\text { Broadcasters with yolky eggs and } \\
\text { facultative planktotrophic larvae }\end{array}$} & & & \\
\hline & Gonad (females) & & $85.32 \pm 1.88(6)$ & $25.78 \pm 3.16(6)$ & $4.45 \pm 1.41(4)$ \\
\hline & Gonad (males) & & $86.10 \pm 0.83(7)$ & $19.21 \pm 0.52(3)$ & $11.76(1)$ \\
\hline & Pyloric caeca & & $83.80 \pm 1.17(7)$ & $22.66 \pm 0.65(17)$ & $4.90 \pm 1.15(9)$ \\
\hline & Body wall & & $71.69 \pm 1.13(7)$ & $3.67 \pm 0.11(20)$ & $57.12 \pm 1.51(21)$ \\
\hline \multirow[t]{5}{*}{ Pterasteridae } & Diplopteraster verrucosus & & & & \\
\hline & Gonad (females) & \multirow[t]{4}{*}{$\begin{array}{l}\text { Brooders }(\mathrm{nc})^{\mathrm{e}} \text { with lecithotrophic } \\
\text { embryos* }\end{array}$} & $83.42 \pm 1.80(10)$ & $29.81 \pm 1.38(12)$ & $6.47 \pm 1.51(9)$ \\
\hline & Gonad (males) & & $85.13 \pm 1.63(3)$ & $17.76 \pm 1.59(5)$ & $10.26 \pm 0.92(4)$ \\
\hline & Pyloric caeca & & $87.33 \pm 0.95$ (13) & $23.03 \pm 0.34(16)$ & $4.27 \pm 0.54(16)$ \\
\hline & Body wall & & $81.12 \pm 0.81(8)$ & $6.12 \pm 0.33(16)$ & $46.48 \pm 1.63(16)$ \\
\hline \multirow[t]{5}{*}{ Korethrasteridae } & Peribolaster folliculatus & \multirow{5}{*}{$\begin{array}{l}\text { Broadcasters with eggs with low yolk } \\
\text { content* }\end{array}$} & & & \\
\hline & Gonad (females) & & $87.46 \pm 2.32(5)$ & $22.79 \pm 1.10(10)$ & $7.28 \pm 1.39(10)$ \\
\hline & Gonad (males) & & $87.49 \pm 0.68(6)$ & $20.46 \pm 1.05(5)$ & $9.82 \pm 0.81$ \\
\hline & Pyloric caeca & & $86.00 \pm 1.30(12)$ & $25.90 \pm 1.00(17)$ & $5.02 \pm 0.63(15)$ \\
\hline & Body wall & & $78.95 \pm 0.90(12)$ & $5.50 \pm 0.26(17)$ & $51.17 \pm 1.34(17)$ \\
\hline
\end{tabular}

MEAN \pm SEM. Sample size between parentheses. References: oi oral incubation; $n c$ nidamental chamber

${ }^{a}$ Hyman (1955)

${ }^{\text {b}}$ Pastor de Ward et al. (2007)

${ }^{\mathrm{c}}$ Bosch (1989)

${ }^{\mathrm{d}}$ Bernasconi (1962)

${ }^{\mathrm{e}}$ Moore et al. (2018)

${ }^{\mathrm{f}}$ Fisher (1940)

*Fig. 2, present paper

examined was $23.36 \mathrm{~kJ} \mathrm{~g}^{-1}\left(20.24-26.12 \mathrm{~kJ} \mathrm{~g}^{-1}\right)$, while the mean ED of the body wall was much lower $\left[4.01 \mathrm{~kJ} \mathrm{~g}^{-1}\right.$ (1.88-6.12 $\mathrm{kJ} \mathrm{g}^{-1}$ ), being consistent with its high inorganic material (IM) content (77.14 and 46.48, respectively). The mean IM of female gonads was $7.15 \%$, being Glabraster antarctica the lowest $(4.45 \%)$ and Anasterias pedicellaris the highest (10.46\%). The mean IM for the male gonads was slightly higher (11.53\%), with Cosmasterias lurida the lowest (4.66\%), while A. pedicellaris had the highest with an extreme value of $21.12 \%$. IM of the pyloric caeca ranged widely from $0.88 \%$ (Henricia obesa) to $22.01 \%$ (Odontaster penicillatus), with a mean IM value of $5.68 \%$. The mean value for the IM of the body wall was $57.72 \%$.

\section{Energetics of sea stars with contrasting development modes}

The ED values for gonads showed no significant differences among different developmental modes (One-way ANOVA, $F_{2,37}=1.537, p=0.2285$ ) (Fig. 3a). Female ED was higher than for males in $D$. verrucosus (brooder with nidamental chamber) ( $t$ test, $\left.t_{16}=4.198, p=0.0007\right)$ and $G$. antarctica (broadcaster with yolky eggs and facultative planktotrophic larvae) (Mann-Whitney, $p=0.0 .0357$ ).
However, Peribolaster folliculatus (broadcaster with presumptive planktotrophic larvae) gonads showed no differences between sexes ( $t$ test, $t_{12}=1.617, p=0.1318$ ).

For the ED of the pyloric caeca (Fig. 3b), there were no significant differences in the interaction between sexes and development modes (two-way ANOVA, $F_{2,39}=0.2626$, $p=0.7704$ ) nor between sexes (two-way ANOVA, $\left.F_{1,39}=0.0061, p=0.9379\right)$. On the other hand, $P$. folliculatus showed higher values of ED (Turkey's comparison test) than did D. verrucosus and G. antarctica (two-way ANOVA, $\left.F_{2,39}=14.14, p<0.0001\right)$.

For the ED of the body wall (Fig. 3c), the interaction between sexes and species was not significant (two-way ANOVA, $\left.F_{3,55}=1.539, p=0.2146\right)$, nor were there differences in ED between sexes (two-way ANOVA, $F_{1,55}=0.044$, $p=0.8347)$. However, body wall ED was significantly different among species (two-way ANOVA, $F_{3},{ }_{55}=27.77$, $p<0.0001$ ), being higher for $D$. verrucosus and $P$. folliculatus than other species (Turkey's comparison test).

\section{ED estimations}

There were significant general linear relationships detected for the sea star species examined between $\mathrm{ED}\left(\mathrm{kJ} \mathrm{g}^{-1}\right)$ and 
(a)

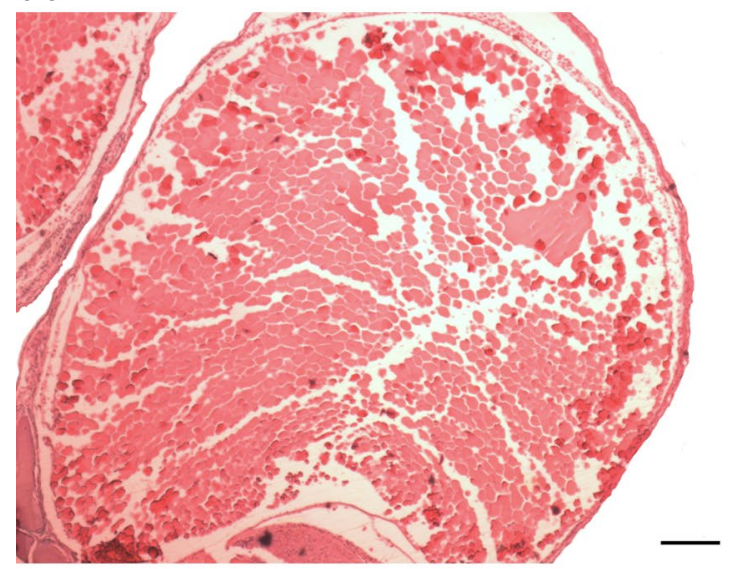

(b)

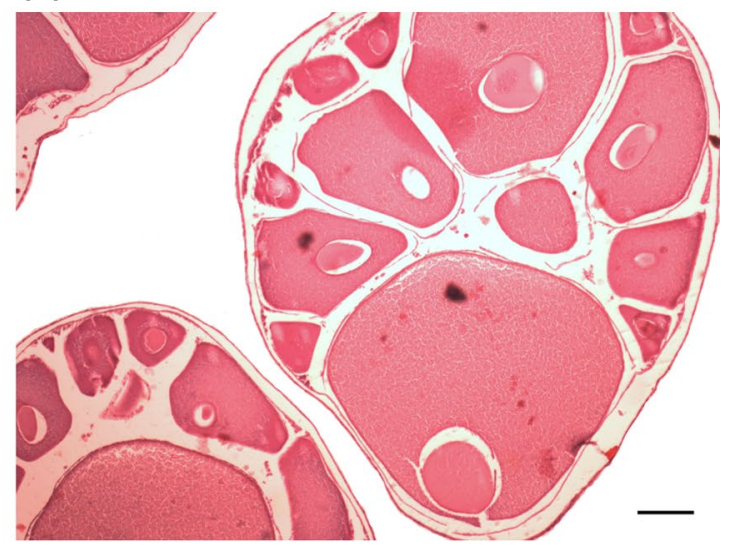

\section{(c)}

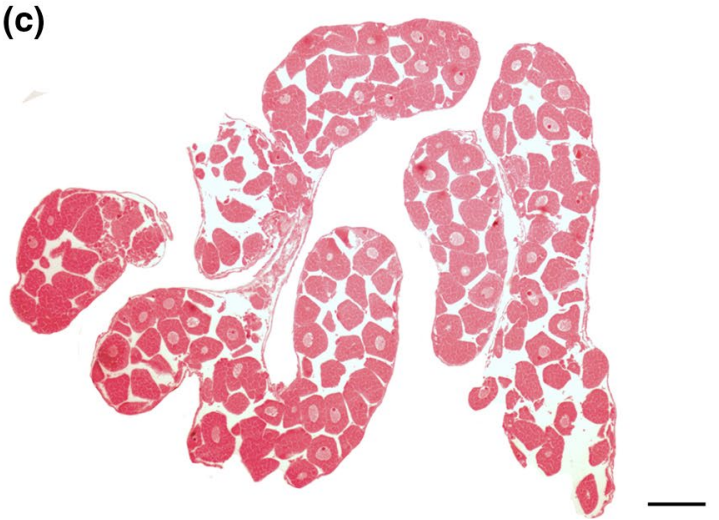

Fig. 2 Histological sections of the gonads of a Anasterias pedicellaris, b Henricia obesa, and c Peribolaster folliculatus. Scale bar $200 \mu \mathrm{m}$

dry mass (DM, \%) among the different body components: gonad: $\mathrm{ED}=8.35+0.97 * \mathrm{DM}, R^{2}=0.47\left(F_{1,16}=14.21\right.$, $p=0.0017)$; pyloric caeca: $\mathrm{ED}=17.65+0.37 * \mathrm{DM}$, $R^{2}=0.25\left(F_{1,19}=6.32, p=0.0211\right)$; and body wall: $\mathrm{ED}=7.99-0.12 * \mathrm{DM}, R^{2}=0.33\left(F_{1,32}=15.59, p=0.0004\right)$ (Fig. 4a, b, c). Moreover, for individual species this relationship was significantly linear: $D$. verrucosus pyloric caeca, $\mathrm{ED}=16.11+0.52 * \mathrm{DM}, R^{2}=0.57\left(F_{1,5}=6.742, p=0.0485\right.$, $n=7) ;$. folliculatus pyloric caeca, $\mathrm{ED}=7.55+1.16 * \mathrm{DM}$, $R^{2}=0.66\left(F_{1,4}=7.735, p=0.0498, n=6\right)$ and body wall, $\mathrm{ED}=1.62+0.17 * \mathrm{DM}, R^{2}=0.38\left(F_{1,9}=5.488, p=0.0438\right.$, $n=11)$; $G$. antarctica pyloric caeca, $\mathrm{ED}=34.08-0.86 * \mathrm{DM}$, $R^{2}=0.91\left(F_{1,2}=19.25, p=0.0482, n=4\right) ; D$. brandti body wall, $\mathrm{ED}=23.64-0.57 * \mathrm{DM}, R^{2}=0.99\left(F_{1,1}=5017\right.$, $p=0.0090, n=3$ ).

\section{Discussion}

The present study provides basic knowledge about the development modes of five species of sea stars to the best of the authors' knowledge are not described. In Anasterias pedicellaris and Lysasterias sp., our observation of broods being held against the adult female mouth indicates that this species has a mode of development involving oral incubation. Moreover, the histological sections of the gonads of presumptive mature females of A. pedicellaris (Fig. 2a) revealed few, large densely packed oocytes with a maximum diameter of $2.44 \mathrm{~mm}$, similar to other known brooders such as Diplasterias brucei (2.80 mm diameter oocyte) (Bosch and Pearse 1990). While, in Henricia obesa and $H$. studeri, the presence of few, large densely packed lecithotrophic eggs with a maximum diameter of $1.03 \mathrm{~mm}$ along with numerous smaller previtellogenic oocytes suggests a lecithotrophic larva (Fig. 2b). This oocyte size is similar to other known broadcasting species with non-feeding yolky larvae [i.e., Bathybiaster loripes $(0.95 \mathrm{~mm})$ and Psilaster charchoti $(0.93 \mathrm{~mm})$, Bosch and Pearse 1990]. With respect to Peribolaster folliculatus, we propose a mode of development involving a planktotrophic larva. This is supported by histological evidence of ovaries with large number of very small mature oocytes (maximum diameter $0.18 \mathrm{~mm}$ ) that will presumably be broadcasted and once fecundated develop into planktotrophic larvae (Fig. 2c). Assuming 

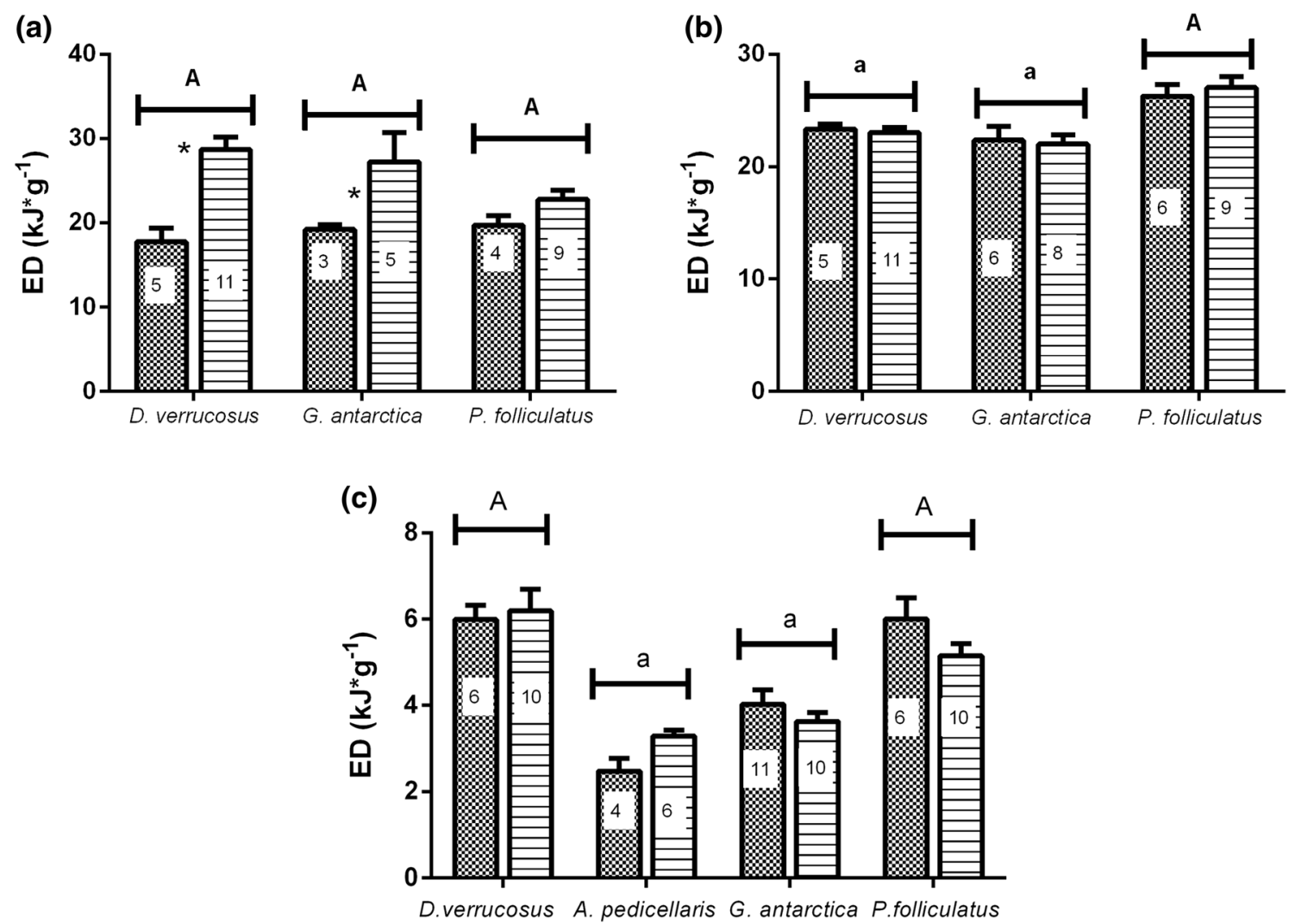

Fig. 3 Energetic density (ED, $\mathrm{kJ} \mathrm{g}^{-1}$ AFDM) of a Gonad, b Pyloric caeca, and $\mathbf{c}$ Body wall of different development modes in asteroids: Diplopteraster verrucosus (brooders with incubation in nidamental chamber; nc), Anasterias pedicellaris (brooders with oral incubation; oi), Glabraster antarctica (broadcasters with yolky eggs and faculta-

individuals were sexually mature when sampled, the maximum diameter of oocytes in P. folliculatus is similar to that described for other broadcasting sea stars with feeding larvae [i.e., Odontaster validus (0.17 mm), Odontaster meridionalis (0.19 mm) (Bosch and Pearse 1990), and Cosmasterias lurida (0.12 mm) (Cossi et al. 2015)].

The high incidence of brooding asteroid species (50\%) found in the NMPA (Fraysse et al. 2018) is in concordance with Pearse et al. (2009) who postulated that the occurrence of many species with non-pelagic development may be a consequence of isolation after vicariant events that led to their proliferation, rather than specific adaptations to conditions in polar seas.

Evidence of a high energy investment of females on reproduction was seen in the species we examined that brood or produce yolky eggs (D. verrucosus and $G$. antarctica, respectively) given the higher ED values of gonads in females than in males (Fig. 3a). Greater energy allocation to ovaries could be related to providing sufficient nutrition to the brood. Some of the essential nutrients required by the broods to develop fully are supplied to the egg during tive planktotrophic larvae), and Peribolaster folliculatus (broadcasters with presumptive planktotrophic larvae). MEAN \pm SEM, sample size on the bars. Color references: checkered, males; lined, females. Significant differences $(p<0.05)$ are indicated by the same capital and small letter (species) and by an asterisk (sex)

vitellogenesis (McClary and Mladenov 1990). Since brooding and lecithotrophic development eliminates a feeding stage and shortens the time larvae spend in the plankton, a high lipid content in lecithotrophic eggs is crucial in providing energy for the production of large-sized individuals at metamorphosis (McClintock and Pearse 1987). Furthermore, a lengthy development period and energy utilization during brooding could compromise the reserves available to the juveniles (Pearse et al. 1991). The lecithotrophic developmental strategy implies a trade-off between the quantity and quality of offspring as brooding involves a high energetic cost and the production of large, slow-developing, nutrient-rich eggs, which often comes at the cost of reduced fecundity (Thatje et al. 2018). The low inorganic matter (IM) values in gonads and pyloric caeca (Table 1), (i.e., low content of ash) is in concordance with their suggested role as energy storage organs in echinoderms (McClintock and Pearse 1987; Pérez et al. 2017). The difference obtained in the percentages of IM of ovaries and testes (Table 1) can be attributed to a larger amount of reserve compounds (organic matter) in females than in males. 
Fig. 4 Linear relationship (lines) between energetic density (ED, $\mathrm{kJ} \mathrm{g}^{-1}$ AFDM) and dry mass (DM, in percentage) for different body components of asteroid species. a Gonads of C. lurida $(n=2), D$. verrucosus $(n=6)$, . folliculatus $(n=7)$, and $G$. antarctica $(n=3)$. All species: $\mathrm{ED}=8.35+0.97 * \mathrm{DM}$, $R^{2}=0.47$. b Pyloric caeca of $C$. lurida $(n=4) ; D$. verrucosus $(n=7), \mathrm{ED}=16.11+0.52 * \mathrm{DM}$, $R^{2}=0.57 ;$ P. folliculatus $(n=6), \mathrm{ED}=7.55+1.16 * \mathrm{DM}$, $R^{2}=0.66 ; G$. antarctica $(n=4), \mathrm{ED}=34.08-0.86 * \mathrm{DM}$, $R^{2}=0.91$. All species: $\mathrm{ED}=17.65+0.37 * \mathrm{DM}$, $R^{2}=0.25$. c Body wall of $C$. lurida $(n=4)$; $D$. verrucosus $(n=6) ;$ P. folliculatus $(n=11), \mathrm{ED}=1.62+0.17 * \mathrm{DM}$, $R^{2}=0.38 ; G$. antarctica $(n=7)$; H. obesa $(n=3) ; D$. brandti $(n=3), \mathrm{ED}=23.64-0.57 * \mathrm{DM}$, $R^{2}=0.99$. All species: $\mathrm{ED}=7.99-0.12 * \mathrm{DM}, R^{2}=0.33$
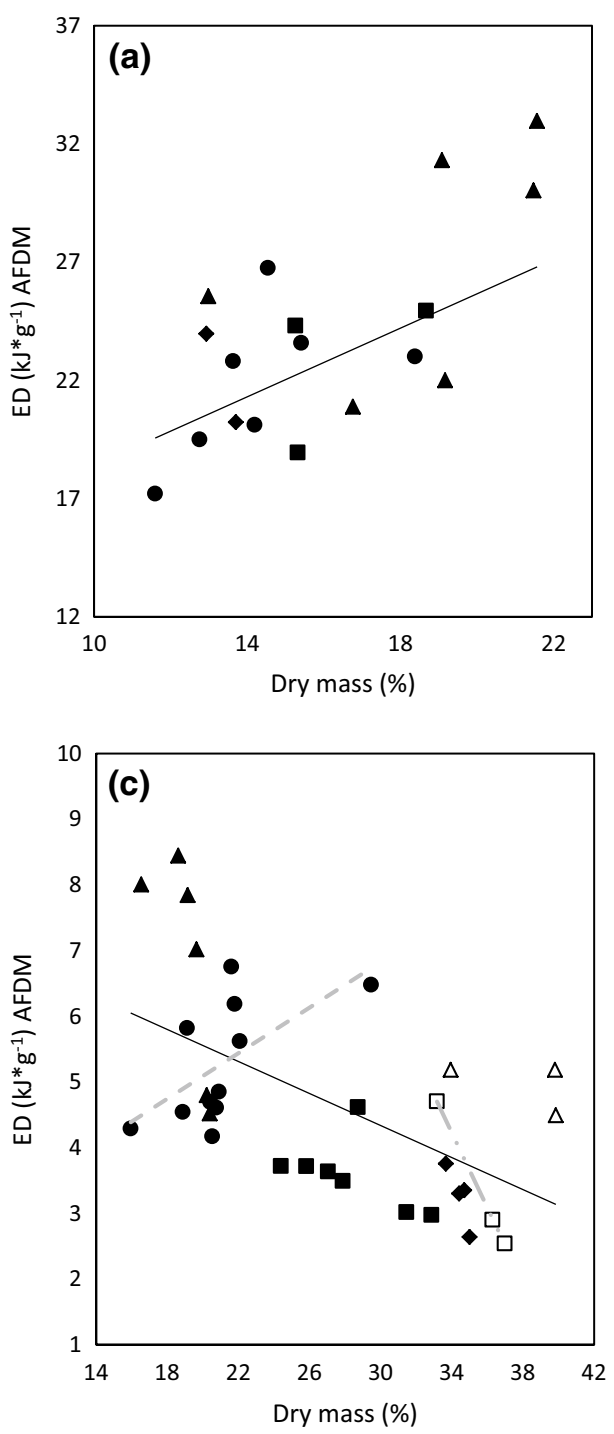
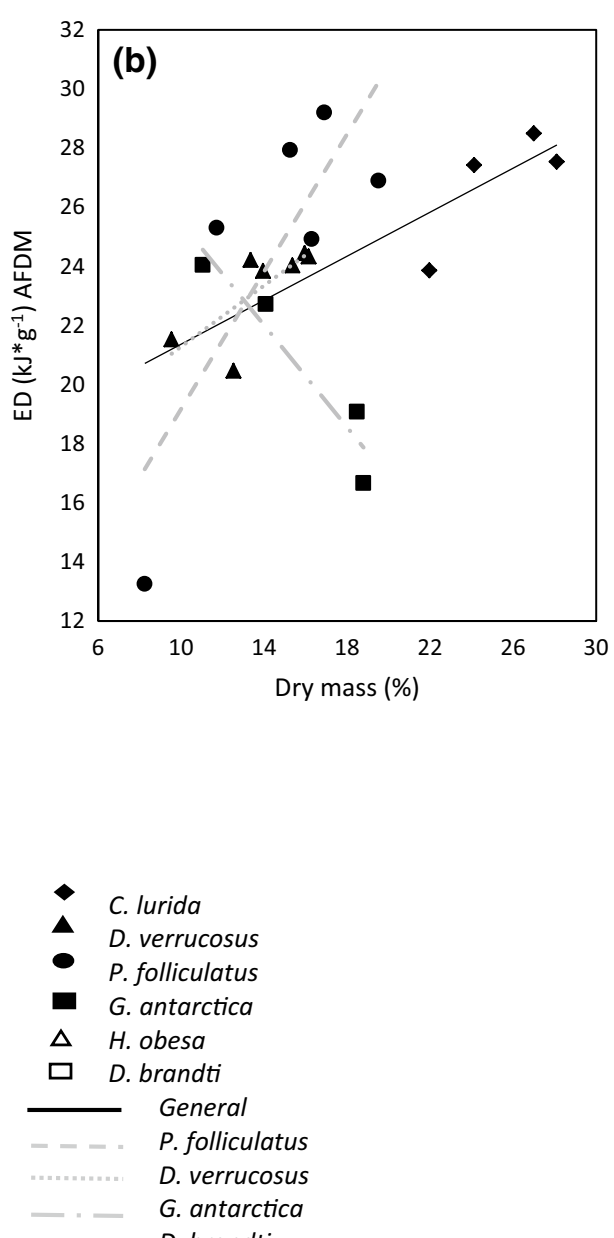

The role of the pyloric caeca as a nutrient storage organ has been well documented before. For instance, McClintock and Pearse (1987) recorded high levels of lipids in the pyloric caeca of antarctic asteroids, which is an advantage over storing energy in the form of lower-energy protein or carbohydrate because more energy can be stored per unit mass. The pyloric caeca is considered an important source of nutrients and energy during gametogenesis (Lawrence and Lane 1982) and functions as a reserve organ in brooding females of species with direct development, especially in species where feeding is impossible during the incubation period (e.g., Anasterias antarctica Pérez et al. 2017). Contrary to what would be expected, differences in energy in the pyloric caeca between sexes were not observed (Fig. 3b). This may be due to a temporal bias given our discrete sampling captured only one time point of the reproductive cycle. For a better understanding of the pyloric caeca role as the energetic reservoir to reproduction, a seasonal study is needed. For instance, the lower ED values found in the pyloric caeca of $D$. verrucosus and G. antarctica compared to P. folliculatus (Fig. 3b) could be the consequence of a higher transference of energy to the gonads for both sexes during gonadal maturation. Though gonadal cycles are well studied in several shallow water sea stars (Bosch and Pearse 1990; Pearse et al. 1991; Cossi et al. 2015; Pérez et al. 2017), less is known about gonadal cycles of species inhabiting deeper depths, such as D. verrucosus, G. antarctica, and $P$. folliculatus.

The high level of IM found in the body walls of asteroids in the present study (46.48-77.14\%, Table 1), is in accordance with those levels reported for echinoids, holothuroids, and ophiuroids (Lawrence and Guille 1982; McClintock et al. 1990). Differences among sea star species in the energetic content of the body wall seems to be purely structural, given the lack of evidences of differential contribution of body wall to the incubation, i.e., lack of differences in ED 
between sexes (Fig. 3c). While analyzing the organic composition of the body wall, Lawrence and Guille (1982) found low levels of carbohydrate and lipids, while protein was reported as the primary organic compound.

Several sea stars such as Pteraster tesselatus, Asterias rubens, Porania pulvillus, and Marthasterias glacialis secrete a mucous through the supradorsal membrane that is utilized as a strong defense mechanism when attacked by other asteroids (Bavington et al. 2004; Hennebert et al. 2012, 2015; Nance and Braithwaite 1979). The mucous contains a saponin or saponin-like compound that after hydrolysis yield various sugars, i.e., galactose, xylose, or glucose (Fieser et al. 1956; Ward 1962; Nance and Braithwaite 1979). The structure of the mucous has also been analyzed by Hennebert et al. (2015), who found it to contain a high proportion of polysaccharides and carbohydrates. As we also observed $D$. verrucosus and $P$. folliculatus to release mucous from their body walls (authors, pers. obs.), the higher values of the ED measured for these species may reflect these secretions and their constituents.

Lawrence and Moran (1992) established energy rather than mass better represents biomass, especially in representatives of the Echinodermata where much of the mass may be inorganic. In the present study, we propose a tool to estimate the ED of different body components of asteroids based on the value of DM (Fig. 4). The data from the studied species showed a relationship between ED and the different body components` DM, enabling the use of the latter as an estimator of ED. This relationship is generally positive for gonads and pyloric caeca, but negative for the body wall. The one exception was for P. folliculatus where we suspect that the inverse relationship in the body wall is explained by its high content of ash (Table 1) and hence, lower levels of organic constituents (lipids, carbohydrates, and protein) that contribute to total ED.. On the other hand, this exception for $P$. folliculatus could be related to the production of mucous secretions (presumably rich in carbohydrates) that effectively reduce total ED.

The present research provides basic information for improving our understanding of patterns of energy allocation among sea stars with contrasting modes of development. Further seasonal and energetic studies are required to better evaluate our initial findings. For instance, it is still unclear whether the body wall may also serve as an energy reservoir for brooding females. However, the differences we detected in the patterns of energy allocation to gonads between sexes provides strong evidence of a higher energy investment to reproduction in females than in males, especially in species that brood or spawn lecithotrophic larvae.

Acknowledgements We are grateful to the crew of the RV "Puerto Deseado" for support during the sampling procedures as well as to Drs. Daniel Roccatagliata and Laura Schejter for their commitment to coordinating the work on board. We also thank the members of Laboratorio de Ecología, Fisiología y Evolución de Organismos Acuáticos (CADIC-CONICET) and Lic. Yamila Becker, Dr. Pablo Di Salvatore, Lic. Sebastian Franzese, and Lic. Virginia García Alonso for their technical assistance during the research cruise. We thank Dr. Gustavo Lovrich, Dr. Isidro Bosch, Dr. J. B. McClintock, and Charlotte Regula-Whitefield for reviewing the manuscript and for their valuable suggestions that have considerably improved the final version. We finally thank Dr. Gustavo Lovrich and James McClintock for their help revising the language.

Funding This study was funded by Fundación Felipe Fiorellino, Universidad Maimónides. This is the scientific contribution 22 of the Marine Protected Area Namuncurá (National Law 26875).

\section{Compliance with ethical standards}

Conflict of interest The authors declare that they have no conflict of interest.

Ethical approval All permissions for collecting samples from the 'Marine Protected Area Namuncurá (MPAN) were issued by its Administrative Council by authorizing and funding the scientific missions. All sampling procedures and experimental manipulations follow the guidelines approved by the Universidad de Buenos Aires (Facultad de Ciencias Exactas y Naturales, Bioterio Central,https://exactas.uba. ar/cicual/).

\section{References}

Almandoz GO, Hernando MP, Ferreyra GA, Schloss IR, Ferrario ME (2011) Seasonal phytoplankton dynamics in extreme southern South America (Beagle Channel, Argentina). J Sea Res 66:47-57

Arntz W, Rauschert M (2015) Antarctic macrobenthos: a feld guide of the invertebrates living at the antarctic seafloor. Arntz \& Rauschert Selbstverlag, Wurster Nordseekueste

Bavington CD, Lever R, Mulloy B, Grundy MM, Page CP, Richardson NV, McKenzie JD (2004) Anti-adhesive glycoproteins in echinoderm mucus secretions. Comp Biochem Physiol B 139:607-617

Bernasconi I (1962) Asteroideos Argentinos III. Familia Odontasteridae. Rev Mus Argent Cienc Nat Bernardino Rivadavia Inst Nac Invest Cienc Nat (Argent), Zool 9(1):1-25

Bernasconi I (1970) Equinodermos antárticos. II. Asteroideos. 3. Asteroideos de la extremidad norte de la Península Antártica. Rev Mus Argent Cienc Nat Bernardino Rivadavia Inst Nac Invest Cienc Nat (Argent) Zool 9:211-281

Blake DB (2000) The class Asteroidea (Echinodermata): fossils and the base of the crown group. Am Zool 40:316-325

Bosch I (1989) Contrasting modes of reproduction in two Antarctic asteroids of the genus Porania, with the descrption of unusual feeding and non-feeding larval types. Biol Bull 177:77-82

Bosch I, Pearse J (1990) Developmental types of shallow-water asteroids of McMurdo Sound, Antarctica. Mar Biol 104:41-46

Bosch I, Slattery M (1999) Costs of extended brood protection in the Antarctic sea star, Neosmilaster georgianus (Echinodermata: Asteroidea). Mar Biol 134:449-459

Boy C, Pérez A, Fernández D, Calvo J, Morriconi E (2009) Energy allocation in relation to spawning and overwintering of a diadromous Puyen (Galaxias maculatus) population in the southernmost limit of the species distribution. Polar Biol 32:9-14 
Broyer C, Koubbi P (eds) (2014) SCAR biogeographic Atlas of the Southern Ocean. Scientific Committee on Antarctic Research Cambridge, UK

Byrne M (1996) Viviparity and intragonadal cannibalism in the diminutive sea stars Patiriella vivipara and P. parvivipara (family Asterinidae). Mar Biol 125:551-567

Byrne M (2005) Viviparity in the sea star Cryptasterina hystera (Asterinidae) - conserved and modified features in reproduction and development. Biol Bull 208:81-91

Calow P (1984) Economics of ontogeny-adaptational aspects. In: Shorrocks B (ed) Evolutionary ecology. Blackwell, Oxford, pp 81-104

Clark AM, Downey ME (1992) Starfshes of the Atlantic, vol 3. Chapman \& Hall, London, p 794

Clarke A (1987) Temperature, latitude and reproductive effort. Mar Ecol Prog Ser 39:89-99

Clarke A, Johnston NM (2003) Antarctic marine benthic diversity. Oceanogr Mar Biol 41:47-114

Cossi PF, Boy CC, Giménez J, Pérez AF (2015) Reproductive biology and energy allocation of the sea star Cosmasterias lurida (Echinodermata: Asteroidea) from the Beagle Channel, Tierra del Fuego, Argentina. Polar Biol 38:1321-1333

Chia FS (1974) Classification and adaptive significance of developmental patterns in marine invertebrates. Thalassia jugosl 10:121-130

Chia F, Walker CW (1991) Echinodermata: asteroidea. In: Giese AC, Pearse JS, Pearse VB (eds) Reproduction of marine invertebrates. Echinoderms and lophophorates. The Boxwood Press, Pacific Grove, vol 6, pp 301-353

De Broyer C, Danis B (2010) SCAR-MarBIN: the Antarctic marine biodiversity information network World Wide Web electronic publication. https://www.scarmarbin.be. Accessed 1 Aug 2017

De Broyer C, Clarke A, Koubbi P, Pakhomov E, Scott F, Vanden Berghe E, Danis B (eds) (2018). Register of Antarctic Marine (RAMS). http://www.marinespecies.org/rams. Accessed 22 Mar 2018

Falabella V (2017) Área Marina Protegida Namuncurá-Banco Burdwood. Contribuciones para la línea de base y el plan de manejo, Buenos Aires

Fernández DA, Lattuca ME, Boy CC, Pérez A, Ceballos SG, Vanella FA, Morriconi ER, Malanga GF, Aureliano DR, Rimbau S, Calvo J (2009) Energy density of sub-Antarctic fishes from the Beagle Channel. Fish Physiol Biochem 35(1):181-188. https://doi. org/10.1007/s10695-008-9234-1

Fieser M, Fieser LF, Toromanoff E, Hirata Y, Heymann H, Tefft M, Bhattacharya S (1956) Synthetic emulsifying agents. J Am Chem Soc 78:2825-2832

Fisher WK (1940) Asteroidea. Disc Rep 20:69-306

Fraysse CF, Clacagno JA, Pérez AF (2018) Asteroidea of the southern tip of South America, including Namuncurá Marine Protected Area at Burdwood Bank and Tierra del Fuego Province, Argentina. Polar Biol 41:2423-2433

Giese A (1966) On the biochemical constitution of some echinoderms. In: Boolootian RA (ed) Physiology of echinodermata. Interscience, New York, pp 547-576

Gillespie JM, McClintock JB (2007) Brooding in echinoderms: How can modern experimental techniques add to our historical perspective? J Exp Mar Biol Ecol 342:191-201

Hennebert E, Wattiez R, Waite JH, Flammang P (2012) Characterization of the protein fraction of the temporary adhesive secreted by the tube feet of the sea star Asterias rubens. Biofouling 28(3):289-303

Hennebert E, Leroy B, Wattiez R, Ladurner P (2015) An integrated transcriptomic and proteomic analysis of sea star epidermal secretions identifies proteins involved in defense and adhesion. J Proteom 128:83-91
Himmelman J, Lavergne Y, Cardinal A, Martel G, Jalbert P (1982) Brooding behaviour of the northern sea star Leptasterias polaris. Mar Biol 68:235-240

Horton et al (2018) World Register of Marine Species (WoRMS) WoRMS editorial board. https://www.marinespecies.org. Accessed 22 Mar, 2018

Hyman LH (1955) The invertebrates: echinodermata, the coelomate bilateria, vol 4. McGraw-Hill, New York

Jagt JW et al (2014) A starfish bed in the Middle Miocene Grand Bay Formation of Carriacou, The Grenadines (West Indies). Geol Mag 151:381-393

Jangoux M (1982) Food and feeding mechanisms: asteroidea. In: Janggoux M, Lawrence JM (eds) Echinoderm nutrition. Balkema, Rotterdam, pp 117-157

Janosik AM, Halanych KM (2010) Unrecognized Antarctic biodiversity: a case study of the genus Odontaster (Odontasteridae; Asteroidea). Integ Comp Biol 50:981-992

Koehler R (1913) Echinodermes (astéries, ophiures et échinides): recueillis par M. Rallier du Baty, aux îles de Kerguelen, en 19131914. Masson

Lawrence JM (1987a) Bioenergetics of echinoderms. In: Keegan BF, O'Connor DS (eds) Echinodermata. Balkema, Rotterdam, pp $47-67$

Lawrence JM (1987b) Functional biology of echinoderms. The Johns Hopkins University Press, Baltimore

Lawrence JM (1987c) Echinoderms. In: Pandian TJ, Vernberg FJ (eds) Animal energetics, vol 2. Academic Press, San Diego, pp 229-321

Lawrence JM, Guille A (1982) Organic composition of tropical, polar and temperate-water echinoderms. Comp Biochem Physiol B $72: 283-287$

Lawrence JM, Lane JM (1982) The utilization of nutrients by postmetamorphic echinoderms. In: Janggoux M, Lawrence JM (eds) Echinoderm nutrition. Balkema, Rotterdam, pp 331-371

Lawrence JM, McClintock J (1994) Energy acquisition and allocation by echinoderms (Echinodermata) in polar seas: adaptations for success. In: Keegan BF, O'Connor DS (eds) Echinodermata. Balkema, Rotterdam, pp 39-52

Lawrence JM, Moran P (1992) Proximate composition and allocation of energy to body components in Acanthaster planci (Linnaeus) (Echinodermata: Asteroidea). Zool Sci 9:321-328

Lieberkind I (1920) On a starfish (Asterias groenlandica) which hatches its young in its stomach. Vidensk Medd Dan Nat hist Foren 72:121-126

Lieberkind I (1926) Ctenodiscus australis Lütken A brood-protecting asteroid. Vidensk Medd Dan Naturhist Foren 82:183-196

Lucas A (1996) Energetics of aquatic animals. Taylor \& Francis, London

MacBride EW (1920) Echinoderma (part II) and Enteropneusta. Larvae of Echinoderma and Enteropneusta. Nat Hist Rep Br Antarct “'Terra Nova'” Exped 1910 Zool 3:83-94

Mah CL (2018) World Asteroidea database. https://www.marinespec ies.org/asteroidea. Accessed 2018

Mah C, Neill K, Eléaume M, Foltz D (2014) New species and global revision of Hippasteria (Hippasterinae: Goniasteridae; Asteroidea; Echinodermata). Zool J Linn Soc 171:422-456

McClary DJ, Mladenov PV (1990) Brooding biology of the sea star Pteraster militaris (OF Müller): energetic and histological evidence for nutrient translocation to brooded juveniles. J Exp Mar Biol Ecol 142:183-199

McClintock J, Cameron J, Young C (1990) Biochemical and energetic composition of bathyal echinoids and an asteroid, holothuroid and crinoid from the Bahamas. Mar Biol 105:175-183

McClintock JB, Pearse JS (1987) Biochemical composition of antarctic echinoderms. Comp Biochem Physiol B 86:683-687

McClintock JB (1994) Trophic biology of Antarctic shallow-water echinoderms. Mar Ecol Prog Ser 191-202 
McClintock JB, Watts SA, Marion KR, Hopkins TS (1995) Gonadal cycle, gametogenesis and energy allocation in two sympatric mid shelf sea stars with contrasting modes of reproduction. Bull Mar Sci 57:442-452

McEdward LR (1995) Evolution of pelagic direct development in the starfish Pteraster tesselatus (Asteroidea: Velatida). Biol J Linn Soc 54:299-327

McEdward LR, Miner BG (2001) Larval and life-cycle patterns in echinoderms. Canad J Zool 79(7):1125-1170

Mileikovsky SA (1971) Types of larval development in marine bottom invertebrates, their distribution and ecological significance: a reevaluation. Mar Biol 10(3):193-213

Moore JM, Carvajal JI, Rouse GW, Wilson NG (2018) The Antarctic circumpolar current isolates and connects: Structured circumpolarity in the sea star Glabraster antarctica. Ecol Evol 8(21):10621-10633

Nance JM, Braithwaite LF (1979) The function of mucous secretions in the cushion star Pteraster tesselatus Ives. J Exp Mar Biol Ecol 40:259-266

OBIS (2018) Ocean biogeographic information system. Intergovernmental Oceanographic Commission of UNESCO. www.iobis.org, Accessed, p 2018

Paine RT (1969) The Pisaster-Tegula interaction: prey patches, predator food preference, and intertidal community structure. Ecology 50:950-961

Pastor de Ward CT, Rubilar T, Díaz-de-Vivar ME, Gonzalez-Pisani X, Zarate E, Kroeck M, Morsan E (2007) Reproductive biology of Cosmasterias lurida (Echinodermata: Asteroidea) an anthropogenically influenced substratum from Golfo Nuevo, Northern Patagonia (Argentina). Mar Biol 151(1):205

Pearse JS, Bosch I (1994) Brooding in the Antarctic: Östergren had it nearly right. Echinoderms through time. Balkema, Rotterdam, pp 111-120

Pearse JS, McClintock JB, Bosch I (1991) Reproduction of Antarctic benthic marine invertebrates: tempos, modes, and timing. Am Zool 31:65-80

Pearse JS, Mooi R, Lockhart SJ, Brandt A (2009) Brooding and species diversity in the Southern Ocean: selection for brooders or speciation within brooding clades? Smithsonian at the poles: contributions to international polar year science. Smithsonian Institute, Smithsonian Institution Scholarly Press, Washington, DC

Pérez AF, Morriconi E, Boy C, Calvo J (2008) Seasonal changes in energy allocation to somatic and reproductive body components of the common cold temperature sea urchin Loxechinus albus in a Sub-Antarctic environment. Polar Biol 31:443-449

Pérez AF, Boy C, Morriconi E, Calvo J (2010) Reproductive cycle and reproductive output of the sea urchin Loxechinus albus (Echinodermata: Echinoidea) from Beagle Channel, Tierra del Fuego, Argentina. Polar Biol 33:271-280

Pérez AF, Boy CC, Calcagno JÁ, Malanga G (2015) Reproduction and oxidative metabolism in the brooding sea star Anasterias antarctica (Lütken, 1957). J Exp Mar Biol Ecol 463:150-157

Pérez AF, Fraysse C, Boy CC, Epherra L, Javier C (2017) Reproductive biology and energetics of the brooding sea star Anasterias antarctica (Echinodermata: Asteroidea) in the Beagle Channel, Tierra del Fuego, Argentina. Rev Biol Trop 65:221-232

Piola AR, Gordon AL (1989) Intermediate waters in the southwest South Atlantic. Deep-Sea Res Oceanogr A 36:1-16

Raymond JF, Himmelman JH, Guderley HE (2004) Sex differences in biochemical composition, energy content and allocation to reproductive effort in the brooding sea star Leptasterias polaris. Mar Ecol Prog Ser 283:179-190

Raymond JF, Himmelman JH, Guderley HE (2007) Biochemical content, energy composition and reproductive effort in the broadcasting sea star Asterias vulgaris over the spawning period. J Exp Mar Biol Ecol 341:32-44

Sabatini M, Reta R, Matano R (2004) Circulation and zooplankton biomass distribution over the southern Patagonian shelf during late summer. Cont Shelf Res 24:1359-1373

Schejter L et al (2016) Namuncurá Marine Protected Area: an oceanic hot spot of benthic biodiversity at Burdwood Bank, Argentina. Polar Biol 39:2373-2386

Sladen WP (1889) Report on the Asteroidea collected by HMS Challenger. Zoology 30:893p

Sokal RR, Rohlf J (1995) Biometry. Freeman, San Francisco, CA

Stampanato S, Jangoux M (1993) Les astérides (Echinodermata) de la Baie Breid (Côte de la Princesse Ragnhild, quartier Enderby, Antarctique), avec la description d'une nouvelle espèce de Solaster. Bull Inst r Sci Nat Belg 63:1785-2184

Stilwell J, Long J (2011) Frozen in time: prehistoric life in Antarctica. Csiro Publishing, Clayton

Studer T (1885) Die Seesterne Süd-Georgiens nach der Ausbeute der deutschen Polarstation in 1882 und 1883. Nat Mus Hmb 2:141-166

Sutton M, Briggs D, Siveter DJ, Siveter DJ, Gladwell D (2005) A starfish with three-dimensionally preserved soft parts from the Silurian of England. Proc R Soc Lond B 272:1001-1006

Tablado A (1982) Asteroideos argentinos Familia Poraniidae. Comun Mus Argent Cienc Nat "Bernardino Rivadavia" Inst Nac Invest Cienc Nat (Argent). Zool 2(8):87-106

Thatje S, Steventon E (1920) Heilmayer O (2018) Energetic changes throughout early ontogeny of the brooding Antarctic sea star Rhopiella hirsuta (Koehler. Polar Biol 41(6):1297-1306

Thomson C (1876) Notice of some Peculiarities in the mode of propagation of certain Echinoderms of the Southern Sea. Zool J Linn Soc 13:55-79

Verrill AE (1914) Monograph of the shallow-water starfshes of the North Pacifc coast from the Arctic Ocean to California. Harriman Alaska Ser 14:1-408

Ward JA (1962) A further investigation of the swimming reaction of Stomphia coccinea. Am Zool 2:567-567

Publisher's Note Springer Nature remains neutral with regard to jurisdictional claims in published maps and institutional affiliations. 